\title{
Current Research on Linguistic Variation in the Arabic-Speaking World
}

\author{
Uri Horesh $^{1 *}$ and William M. Cotter ${ }^{2}$
}

${ }^{1}$ Department of Language and Linguistics, University of Essex

${ }^{2}$ School of Anthropology and Department of Linguistics, The University of Arizona

\section{Abstract}

Given its abundance of dialects, varieties, styles, and registers, Arabic lends itself easily to the study of language variation and change. It is spoken by some 300 million people in an area spanning roughly from northwest Africa to the Persian Gulf. Traditional Arabic dialectology has dealt predominantly with geographical variation. However, in recent years, more nuanced studies of inter- and intra-speaker variation have seen the light of day. In some respects, Arabic sociolinguistics is still lagging behind the field compared to variationist studies in English and other Western languages. On the other hand, the insight presented in studies of Arabic can and should be considered in the course of shaping a crosslinguistic sociolinguistic theory. Variationist studies of Arabic-speaking speech communities began almost two decades after Labov's pioneering studies of American English and have flourished following the turn of the 21 st century. These studies have sparked debates between more quantitatively inclined sociolinguists and those who value qualitative analysis. In reality, virtually no sociolinguistic study of Arabic that includes statistical modeling is free of qualitative insights. They are also not flawless and not always cutting edge methodologically or theoretically, but the field is moving in a positive direction, which will likely lead to the recognition of its significance to sociolinguistics at large.

\section{Introduction: The Foundations of Arabic Sociolinguistics}

Beginning in earnest at the end of the 19th century, the emergence of the English dialectological tradition formed the backbone of contemporary sociolinguistic research. Modern sociolinguistics, especially the early work that focused on describing language variation and change in English-speaking communities, can be seen as an organic product of this dialectological tradition. In the mid part of the 20th century, dialectological work began to take on a more socially informed flavor, culminating in the early work of scholars like Labov (1966) and Trudgill (1974), forming the early generation of sociolinguists that lay the foundation of the field.

Although the history of Arabic dialectology goes almost as far back as its English counterpart (e.g., Bergsträßer 1915), it could be argued that Arabic sociolinguistics has grown less naturally out of its own dialectological tradition. When looking at the early generation of Arabic sociolinguists, we see that most trained under the preeminent scholars of English sociolinguistics at the time. Scholars like Niloofar Haeri (1996) and Hassan Abdel Jawad (1981, 1987) were both students of William Labov and Gillian Sankoff, while Enam Al-Wer (1991, 2007) was a student of Peter Trudgill. That these early scholars began from the starting point of the general study of sociolinguistics may have played a role in creating a situation we see today, with Arabic dialectology and sociolinguistics existing side by side.

\section{From Dialectology to Sociolinguistics in Arabic Research}

Nowadays, scholars of Arabic sociolinguistics still rely a great deal on the work of dialectologists. This is partly the case because Arabic dialectology remains vibrant, with a wealth of new 
research being published on a regular basis from all over the Arabic-speaking world. However, the reliance within Arabic sociolinguistics on the dialectological tradition also manifests in the utilization of texts and grammatical descriptions collected many decades prior. This is especially true when sociolinguists work on varieties of Arabic that have not been the focus of scholarly attention for some time. The result is a situation where Arabic sociolinguists are forced to rely on descriptive sources that are sometimes tragically out of date, or simply unavailable, given that many Arabic vernacular varieties are still undescribed. Notwithstanding, much of the work done in recent years on variation and change in Arabic relies heavily on fresh data, collected by the scholars themselves through sociolinguistic interviews, extended ethnographies, and similar contemporary methods.

We can view this situation as both a blessing and a curse. One argument may be that the dearth of descriptive research on some varieties complicates the job of Arabic sociolinguists because they may begin their work from a descriptively impoverished foundation. This phenomenon is not inherently unique to the Arabic sociolinguistic enterprise. Recent works on English, especially in smaller, peripheral, and rural areas have also served as first-ever discoveries of hitherto undocumented features of the language. This is evident in much of the work done in Appalachia and the American South ( for a multitude of examples, see American English by Wolfram and Schilling [2015, most recent edition]), as well as in most of the UK ( for a tip-of-the-iceberg taste of studies on British English, consider the two distinct editions of Language in the British Isles, the original edited by Peter Trudgill in 1984 and the second edited by David Britain in 2007).

Dialectal descriptions are beginning to make their way into doctoral dissertations as an integral part of the larger sociolinguistic enterprise (e.g., Al-Qahtani 2015). We also see sociolinguists of Arabic doing 'double-duty' and attempting to interface more regularly with Arabic dialectology through conference presentations that cross disciplinary boundaries and bridge the divide between traditional dialectology and sociolinguistics (Leddy-Cecere 2015, Schroepfer 2015).

The importance of this descriptive work cannot be overstated, but the current situation, with Arabic sociolinguists playing multiple roles over the course of their work, may be one contributing factor to the current status of the subfield as theoretically lagging behind mainstream sociolinguistics. The reality is that Arabic sociolinguistics has yet to fully breach the theoretical threshold of third-wave sociolinguistics. In this respect, a great deal of the work being conducted on language variation in Arabic still focuses on the types of questions that sociolinguists were concerned with decades before. Our own recent work (Cotter 2016, Cotter \& Horesh 2015, Horesh \& Cotter 2015, Horesh 2015) certainly falls into that category, though we have attempted to delve, if only superficially, into more profound matters of identity, politics, and religion. This necessary focus on both linguistic description and analyses of language variation and change may result in less attention to further developing sociolinguistic theory. Instead, Arabic sociolinguists often rely on established theories developed in predominantly Western, English-speaking communities and test their applicability to the Arabic case.

The work carried out in Arabic sociolinguistics has shown us that general sociolinguistic theory bears out for Arabic as well. Importantly, this has made it clear that despite multiple attempts to emphasize that Arabic is a 'diglossic' language (or, indeed, that the speech communities that use Arabic as their primary language are, for the most part, diglossic), Arabic is not a special case sociolinguistically, a notion suggested in earlier work (Labov 1982). In this sense, Arabic follows all the norms and patterns established and expounded upon by sociolinguistics generally.

Lotfi Sayahi (2014) taps into the very question of diglossia and its relation to a more general theory of sociolinguistic variation. He reviews previous definitions of diglossia, starting with scholars preceding Ferguson, and through to Eckert (1980), whose insights on diglossia have broad applications for general sociolinguistics. Sayahi relies in his analysis of diglossia in the speech communities of Tunisia, Algeria, and Morocco on contemporary sociolinguistic theory. 
Another excellent example can be found in Alghamdi (2014). As a precursor to her study of Arabic diphthongs among rural migrants in Mecca, she not only surveys the history of studies involving the diphthongs /ai/ and /aw/ in Arabic dialects, but also begins with a recapitulation of the well-known study of phonetically similar variables by Labov (1972) in Martha's Vineyard, Massachusetts. Furthermore, drawing on work by Chambers (1992), Alghamdi cites an analogous case of migrants versus natives in the Netherlands. This kind of comparative analysis, dating back to scholarly traditions in historical linguistics and linguistic typology, is crucial to sociolinguistics, as it not only draws upon linguistically comparable cases but also contributes to linguistic theory more broadly.

Perhaps we can learn a lesson from work done by sociolinguists on pidgin and creole languages (e.g., Meyerhoff and Walker 2013; Sidnell 2001, 2012; and Singler 1990). Similar to the case of Arabic, a great deal of the work conducted in pidgin and creole studies has taken two separate but connected tracks, one focused more heavily on documentation and description of these language varieties, with the other treating pidgins and creoles through the lens of sociolinguistics in an effort to uncover how the analyses of these contact situations can further inform and refine general sociolinguistic theory.

Many of the types of contact taking place in the Arabic-speaking world are not as profound as in the bulk of pidgin and creole cases. ${ }^{1}$ While many of these situations of contact may be similar, the contributing factors leading to this contact are quite dynamic, with a sizable portion of the dialect contact happening in the Arabic-speaking world in recent years being a result of war, forced migration, and protracted political conflict. Investigating the relationship between these factors and language change represents an area that Arabic sociolinguistics has yet to fully exhaust.

\section{State of the Field}

One element that is essential to most variationist studies, regardless of their specific theoretical leaning (e.g., sociophonetics, communities of practice, sociohistorical) is that they tackle what one might call instances of microvariation. By this, we mean that in addition to a macrodescription of a language variety, a set number of linguistic variables are analyzed. Doing so enables one to ascertain the significance of speakers' use of the range of variants each such variable may have for the speech community in question. Very often, these variables are phonological, but there is no shortage of variables examined over the years (not necessarily in Arabic) from other domains of linguistic analysis, such as morphology, syntax, and pragmatics. A typical analysis of microvariation - especially for phonological variables - within a speech community involves some sort of quantitative analysis. The role of statistical methods for the study of language variation has been adopted by sociolinguists of various persuasions. As Labov (1994:26) argues 'the theory-free character of these methods can yield exceptionally strong conclusions when the results coincide with the categories predicted by a particular theory'.

Within Arabic sociolinguistics, the variationist paradigm, and more specifically, the quantitative approach that characterizes much of its methodology, has known a few critics, most notably Yasir Suleiman. In a recent monograph (Suleiman 2011:13), he chastises 'the obsession with quantities', which in his view is 'expressed as percentages of language use vis-à-vis populations of speakers [...] [and] in tables and bar charts with comments on standard deviations about the occurrence of this or that linguistic variant in the research population'. Suleiman acknowledges that 'this kind of analysis is necessary and important in understanding the sociolinguistics of Arabic'. However, he also opines that there is an 'enemy' (15) to what he dubs 'correlationalist-variationist research' in 'the injection of external or ideological research agendas that can skew the findings of correlationalist-variationist research in a predetermined manner'. 
Suleiman's critique of the variationist paradigm has been eloquently criticized by Clive Holes in a review article of his 2011 book (Holes 2015). He calls Suleiman's approach 'superficial, uninformed, and out-of-date' (99) and notes that his work completely ignores 'the second and third waves of LVC [Language Variation and Change]', as represented by the works of Lesley Milroy and Penelope Eckert (e.g., Milroy 1987 and Eckert 2000), among many others. According to Holes (2015), Suleiman is wrong in positing that

those who work in it [the variationist approach] have failed to follow his path into the identity-based study of variation. As he tortuously puts it (p.15): "this approach [LVC] elides that in-between space of liminality that requires a multiplicity of perspectives to excavate it." But as a matter of fact, many researchers in LVC in Arabic, as in other languages, long ago moved beyond its initial incarnation.

We share Holes's view, not only in his criticism of Suleiman but also in our recognition of the contributions of variationists (Holes included) to the study of Arabic sociolinguistics. Ironically, perhaps, such contributions do, in fact, shed light on matters of ideology and provide intricate reasoning for the use of linguistic variants. The manner in which variationist studies of Arabic have employed quantitative methods goes far beyond the tables and graphs, mocked by Suleiman. Much of the work on Arabic, even before Labov's groundbreaking studies of Martha's Vineyard, New York City, and Philadelphia, included in its analysis such issues as language ideology (cf. Ferguson 1959²) and religious affiliation (cf. Blanc 1953, 1964), two objects of inquiry that were introduced into 'Western' sociolinguistics only decades later. ${ }^{3}$

Several previous summaries of Arabic sociolinguistics have been published since the end of the 20th century. Keith Walters published a paper in the 1996 volume of Perspectives on Arabic Linguistics, analyzing diglossia in light of recent research in theories of language contact, language variation and change, and code-switching. In 2000, Niloofar Haeri published an insightful article in that year's Annual Review of Anthropology, expanding the discussion of Arabic sociolinguistics beyond the sphere of the variationist paradigm into anthropology and related social sciences. Finally, Jonathan Owens contributed two pieces entitled 'Arabic Sociolinguistics': one as an article in the 2001 volume of the journal Arabica and the other as a chapter in the 2011 tome, The Semitic Languages: An International Handbook.

In what follows, we wish to fill in a few gaps in the overall treatment of variationist studies of Arabic. We do so through concrete examples from recently published works in the field, as well as from yet unpublished doctoral theses, which we believe to be paving the road for future studies in Arabic sociolinguistics. We limit ourselves to such works that were written in the first decade and a half of the 21st century, and in order to avoid redundancy, we refrain in our exposition of recent contributions to the field from citing much of our own work. In what follows, we present and discuss a handful of other representative studies.

Holes (1987) opened a window into language variation in the Arabian Peninsula in his detailed study of Bahrain. Bruce Ingham (in his 1994 book and elsewhere) presents an abundance of dialectological information based on data collected in the country that comprises the majority of the peninsula, Saudi Arabia. A number of $\mathrm{PhD}$ theses have been carried out at the University of Essex, under the supervision of Enam Al-Wer (whose variationist work on dialect formation in Jordan has been discussed in previous summaries of the field), exploring hitherto underrepresented regions of Arabia from a variationist perspective. Three such theses are Alessa (2008), Alghamdi (2014), and Al-Qahtani (2015).

In Al-Wer and Al-Qahtani (2016; based in part on Al-Qahtani's aforementioned thesis), a fine-grained analysis of the voiced pharyngealized lateral fricative $(3)$ is presented, based on data from Tiha mat Qahta $\mathrm{n}$ in southwest Saudi Arabia. This is an interesting relic of Old Arabic, present as a variant of the Proto-Semitic phonemes $* \zeta^{\mathrm{C}}$ and $\partial^{\mathrm{S}}$, both of which are often realized 
in contemporary Arabic dialects as either $\left[\mathrm{d}^{\complement}\right]$ or $\left[\mathrm{\partial}^{\complement}\right]$, depending on whether the dialect has interdental fricatives (other interdentals include $/ \partial /$ and $/ \theta /$, which in many, mostly urban, dialects merge with $/ \mathrm{d} /$ and /t/, respectively). More on this feature from a sociohistorical perspective is available in Al-Wer (2004).

Unlike many other dialects, where a non-lateral voiced pharyngealized interdental fricative $\left[\partial^{\complement}\right]$ represents a conservative variant, in this community, $\left[\partial^{\complement}\right]$ is the innovative variant, with the lateral variant being the conservative one. Figure 1 illustrates that the innovative variant is relatively rare for both women and men of the older generation, but while young men retain roughly the same rate of innovation as their older counterparts, younger women's production of this variant is more than four times that of older women.

In quantitative sociolinguistics, one of the most useful tools used to discern whether a particular factor group (be it linguistic or social) is significant, is a multivariate analysis. This is a mathematical model that assumes that certain linguistic rules are variable rules. A computer program whose name alludes to this concept, VarbRul, has been in use since originally conceived by David Sankoff in the 1970s (see Tagliamonte 2006 for more detail). In recent years, a program called Rbrul, named after the $\mathrm{R}$ statistical programming language in which it is written, has been used in its lieu (Johnson 2009). Al-Wer and Al-Qahtani have used Rbrul in order to tease out the factor groups that are statistically significant for the production of the innovative variant [ $\mathrm{\partial}^{\complement}$ ] in this Saudi community.

As suggested by Figure 1, female speakers show a higher tendency than male speakers to produce the innovative variant. Rbrul has determined that this 'favoring' of women for this variant is statistically significant $(p<0.0005)$. The age distinction is also significant $(p<5 \mathrm{e}-12)$, with younger speakers leading the change. Other factors found to be significant are of a more linguistic nature. Phonological environment is significant $(p<0.001)$, and - quite interestingly as it is not an oft-considered factor - the etymology of the phoneme (recall that we are dealing with two historically distinct phonemes that may be merging) is significant $(p<0.001)$ as well.

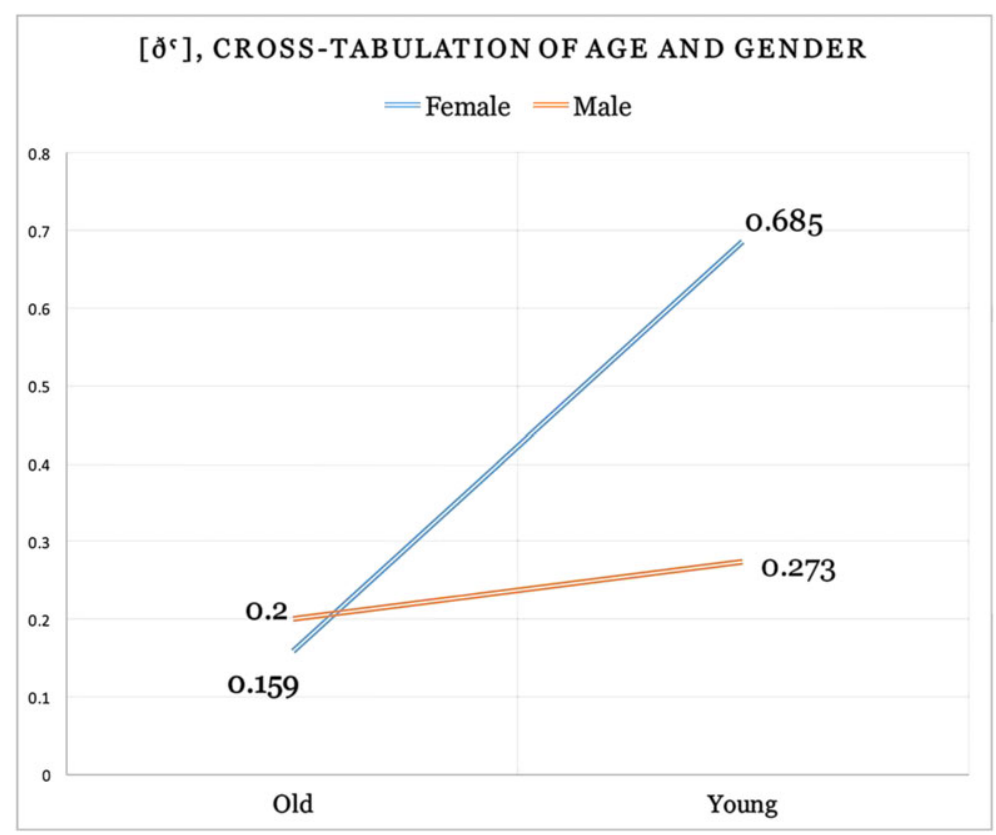

Fig. 1. Based on Al-Wer and Al-Qahtani (2016). 
Alessa (2008) examines another well-known phonological feature in Arabic, affrication of dorsal stops. Arabic, in its most conservative form, only has one affricate, [b], but many localized varieties have such affrication processes as $/ \mathrm{k} />[\mathrm{t}]$, either phonologically conditioned by adjacent high front vowels, as in traditional Jordanian dialects, e.g., that of Salt (Herin 2010; Herin \& Al-Wer 2013) and some Palestinian villages, or categorically in other parts of Palestine. Alessa tackles not only the affrication of the voiceless velar fricative $/ \mathrm{k} /$ (the result of which, unlike the Palestinian case, is often [ts], not [t]]) but also the affrication of /.gscr;/ to [dz]. Why is this so interesting? Primarily because [g] itself is a non-standard reflex of one of the most widely researched phonological variables in Arabic, the phoneme represented orthographically in Arabic as (typically transcribed as /q/). In many dialects, /q/ is pronounced [g] (e.g., in Upper Egypt and Sudan, in Jordan, in the Palestinian Nagab desert, and across much of Mesopotamia and the Arabian Peninsula). That this realization of the / $\mathrm{q} /$ has become phonemicized in parts of Saudi Arabia, creating a new local standard, $/ \mathrm{g} /$, means that it is now the voiced counterpart of $/ \mathrm{k} /$, and can be affricated in an analogous manner to it.

Alessa's subjects are speakers originally of Najdi dialects. These are mostly rural and Bedouin varieties from the central region of Saudi Arabia. But they have relocated to the Hijazi (i.e., western Arabian) city of Jeddah, whose population is approximately three million. The affricated variants described above are part of their native dialect, but not of the urban center in which they now reside. Thus, what often happens is that these speakers deaffricate [ts] to [k] and [c] to [g]. Alessa (2008:57) summarizes this phenomenon in the following two paragraphs:

The disappearance of stem [ts] and [cz] can be ascribed to "the greater awareness attached to overtly stigmatized forms" (Trudgill 1986:11). Najdis in Hijaz are aware of the social stigma associated with this highly "marked" feature that is associated with rural or Bedouin population. So the salient "localised" variants $[\mathrm{s}]$ and $[\mathrm{k}]$ are abandoned in favour of the high status variants $[\mathrm{g}]$ and $[\mathrm{k}]$.

$[\ldots]$

The accommodation of Najdi speakers to the Urban Hijazi is fairly complex, and involves the acquisition of a new paradigmatic distribution, in addition to deaffrication and the reliance on vocalic distinctions. Given this complexity, one would expect that in a process of second dialect acquisition or dialect convergence, interdialectal forms, which do not match the target features, are likely to be used.

These statements are supported by an intricate set of calculations, based on a host of linguistic and social factors, such as whether the underlying velar is in the stem of the word or a suffix (in which case it can denote grammatical gender), phonological environment, age and gender of the speaker, and degree of dialect contact.

\section{Language Variation and Change in the Arabic-speaking World Moving Forward}

One area of interest that perhaps deserves greater emphasis from within Arabic sociolinguistics is a focus on the importance of description of Arabic varieties as part of sociolinguistic work more generally. Many varieties of Arabic are, by most standards, becoming endangered. Increased urbanization leads to koinéization, and many speakers of non-urban dialects gradually immerse themselves in the speech of the nearest city. In some cases (the most prominently documented case is probably that of Amman, Jordan, described extensively by Enam Al-Wer), new urban dialects are created, accepting input from both urban and rural dialects and even different ethnicities. We have not, however, reached a stage where endangered varieties of such a widespread language as Arabic are considered 'endangered enough' in the broader linguistic community.

Descriptive methodologies can be built into our fieldwork and research design, constructing studies that result in substantial descriptive information, without detracting from the depth and 
quality of our sociolinguistic data. We would not only serve sociolinguistic ends but also have the potential to build another body of literature that fills gaps in the Arabic dialectological tradition. This is increasingly important given the massive social and demographic shifts that have taken place throughout the Middle East and Africa in recent decades.

One area that can foster an additional upswing in descriptive work on Arabic emanating from within sociolinguistics is establishing collaborative relationships with members of the Arabic dialectological community. These collaborations can lay the foundation for more complete linguistic descriptions of previously unstudied varieties of Arabic, while the products of these descriptive endeavors will help to further inform later sociolinguistic work that will conceptualize language change. Collaborative endeavors like the work by Al-Wer and Herin (2011) have provided dialectologically grounded treatments of sociolinguistic variation in the Arabicspeaking world. Additional work of this nature is beneficial not only because of the potential scholarly output that these collaborations can bring, but it also helps to create more informed and better trained researchers who understand more holistically the nature of the language communities in which they work.

In addition to the potential for integration of linguistic description and sociolinguistics, innovative sociolinguistic work is emerging that treats newer areas within sociolinguistics through the lens of Arabic. Arabic sociolinguistics is beginning to engage more directly with mediarelated data (Bettega 2015, Hachimi 2013, Hachimi 2015). Important in this area is ongoing work that examines language ideologies in the Arabic-speaking world through venues like Facebook, which prove to be a rich site for metalinguistic data related to spoken Arabic varieties. At the same time, research is being conducted that addresses issues of linguistic style (Al-Shihry 2015), in a manner approximating third-wave sociolinguistic studies elsewhere. This work has the potential to further inform sociolinguistic research on style while destabilizing the largely Western-centered focus of earlier research.

Continued research on Arabic also stands to contribute a great deal within the realm of sociophonetics. One area of sociophonetic concern that has received attention from scholars of Arabic is research on acquisition and bilingualism. Work by researchers such as Khattab et al. (2006) and Khattab $(2007,2009,2013)$ represent the bulk of our current sociophonetic knowledge of Arabic. A collection of useful literature on Arabic phonetics was also published by Hassan and Heselwood (2011), but there is still ample room for further contributions to sociophonetic research on Arabic. Given the great degree of migration and contact that have taken place in the Arabic-speaking world in recent decades, further research could result in a more nuanced sociophonetic perspective on Arabic dialect contact.

As noted above, the study of Arabic sociolinguistics today is also a study of the effects of many sociopolitical forces on language variation and change. This positions Arabic sociolinguistics such that research of this nature has the potential to push forward into new areas of theoretical development, as the effects of these social and political forces on language remain largely undiscussed. In concert with these large-scale changes, the Arabic-speaking world remains an interesting site of mass urbanization and economic migration, creating linguistically diverse urban spaces like Dubai or Qatar that host not only speakers of many different Arabic varieties but also other languages entirely (Theodoropoulou 2015). Sociolinguistic research on these communities is scarce, so the effects of this type of contact and a nuanced understanding of its underlying motivations remain opaque.

Perhaps one of the larger questions remaining in the study of Arabic sociolinguistics is whether or not the field can or should follow other areas of sociolinguistic research and begin to more regularly interface with anthropological - and other social scientific - methods and analyses. At present, studies on Arabic that interface directly between variationist sociolinguistics and anthropological concern remain largely unconsidered, evidenced by other recent 
treatments of the field that have noted the absence of this type of research (Owens 2011). Although it has not been fully explored, the foundation is there, given the wealth of anthropological work carried out in the wider Middle East, a great deal of which focuses on language. Anthropological studies that have treated linguistic issues can be found in communities in Morocco (Hoffman 2008), Egypt (Abu Lughod 1986, Haeri 2003), Yemen (Caton 1990, Miller 2007), the Sahrawi community of North Africa (Deubel 2010), as well as pan-Arab television programs that cross regional borders (Schulthies 2015).

However, much of this work focuses less on the types of linguistic analyses that are often seen to be the core of variationist sociolinguistic research and more on issues lying at the intersection of identity and language practice. Still, this type of work sets the stage for research that bridges the gap between anthropological interests and the kind of research that is more in line with a great deal of the sociolinguistic literature. Recent work at the intersections of Arabic sociolinguistics and other social scientific disciplines has shown that insights from scholars outside of the realm of language can inform and enrich our understanding of how linguistic variation fits into large social, cultural, and political systems. Work by Miller (2008) has highlighted the ways in which area studies can add to this endeavor, while more recent research by Al-Wer et al. (2015) has included insights from scholarship in international relations that has enriched the sociolinguistic base of this work.

\section{Conclusions}

Practically, the methodologies adopted in the recent work discussed above may provide a better foundation for understanding the connections between linguistic practice and the sociopolitical forces that are such a profound part of daily life for the communities in question. A coalescence of anthropological tenets and lines of inquiry more akin to sociolinguistics may provide the recipe for a better understanding of these issues, crucially, one that grounds the study of linguistic practice in the Arabic-speaking world more directly in the lived experiences of people in the community.

We conclude by raising a much more general and decidedly non-linguistic point of concern. Particularly in the West, a general stigma about the Middle East as a region and a lack of understanding about Arabic as a spoken language continually dampens public opinion about the regions in which we work. Sociolinguists working with Arabic-speaking communities are in a unique position to work towards changing that. Many of us have spent a great deal of time in the region, while typically being in a privileged position in that many of us are from predominantly Caucasian, English-, French-, or German-speaking communities. Whether we acknowledge it or not, we are in a position of relative power and privilege. By engaging with the general public about our work and the region generally, we have at least the potential to harness that privilege for something of potential benefit for the communities we work in.

At the same time, by engaging with the communities that we work with, we have the potential to foster a larger interest in documenting Arabic varieties, which are generally still devalued throughout the region. By taking a more anthropological approach that not only focuses on forms of variation, we can highlight the importance of dialectal forms of speech while tying them to wider verbal art forms like oral poetry and popular song (Holes and Abu Athera 2009, 2011, Holes 2013), which hold weight in many parts of the Arabic-speaking world. In doing so, we may be able to work towards a wider acceptance of and increase in respect for the spoken language within communities themselves. 


\title{
Short Biographies
}

Uri Horesh is a British Academy Postdoctoral Fellow at the University of Essex, having earned his $\mathrm{PhD}$ there in 2014. He has taught Arabic as a foreign language in a host of higher education institutions in the USA. He has served as the Founding Director of the Arabic Language Program at Franklin \& Marshall College and as Language Coordinator in the Middle East and North African Studies Program at Northwestern University. His interests include language contact as a vehicle for language change, the comparative study of Semitic languages (especially Arabic and Hebrew in historic Palestine) and variationist sociolinguistic theory. He is co-editing the Routledge Handbook in Arabic Sociolinguistics with Enam Al-Wer, as well as in the process of co-authoring a Cambridge textbook in the field with Al-Wer, Rudolf de Jong, and Bruno Herin. Among other publications, he has authored, with William Cotter, an article in Journal of Sociolinguistics and a lemma on the sociolinguistics of Palestinian Arabic in the Encyclopedia of Arabic Language and Linguistics Online.

William Cotter is a Doctoral Student in the joint Anthropology and Linguistics program at the University of Arizona. His interests include dialect contact and change in Palestinian varieties of Arabic, sociophonetics of Arabic varieties, the relationship between protracted political conflict and language change in the Middle East, variationist sociolinguistics, and linguistic anthropological theory. He has authored a piece in the recent Perspectives on Arabic Linguistics XXVIII volume, as well as co-authored, with Uri Horesh, a lemma on the sociolinguistics of Palestinian Arabic in the Encyclopedia of Arabic Language and Linguistics Online and an article in the Journal of Sociolinguistics. He received his BIS in Middle Eastern Studies from Georgia State University and his MA in Sociolinguistics of the Arab World from the University of Essex.

\begin{abstract}
Notes
* Correspondence address: Uri Horesh, Department of Language and Linguistics, University of Essex, Wivenhoe Park, Colchester, CO4 3SQ, UK. E-mail: urihoresh@gmail.com
\end{abstract}

1 However, it is important to note that Arabic has its own collection of pidgins and creoles for which it serves as a lexifier language; see Tosco and Manfredi 2013, the special 2014 issue of Journal of Pidgin and Creole Languages [29:1], especially Owens 2014 within that issue; also cf. Versteegh 1984 and Hary 1996, both of whom liken the continuum of Arabic varieties to the continuum evidenced in pidgin and creoles. In later works (e.g., Versteegh 2004), Kees Versteegh revisits his original theory and thoroughly adjusts it.

2 Bill Labov himself, who is widely known as the 'founding father of modern sociolinguistics', wrote about Ferguson: 'When I first entered the field of linguistics, sociolinguistics had already been created, and the most important general statement of its principles is still to be found in Ferguson and Gumperz's introduction to Linguistic Diversity in South Asia (1960)'. (Labov 2003:5). While Labov's brief reflection on Ferguson's contribution to sociolinguistics does not mention his 1959 article (re)defining 'diglossia' in the context of Arabic and three other cases, there is virtually no Arabic linguist who has not read, referenced, and/or taught this article.

${ }^{3}$ Germanos and Miller (2014) provide a recent overview of work that views religious affiliation as a factor in Arabic sociolinguistic research.

\section{Works Cited}

Abdel Jawad, Hassan. 1981. Lexical and phonological variation in spoken Arabic in Amman. PhD dissertation, University of Pennsylvania.

Abdel Jawad, Hassan. 1987. Cross-dialectal variation in Arabic: competing prestigious forms. Language in Society 10: $359-67$. Abu-Lughod, Lila. 1986. Veiled sentiments: honor and poetry in a Bedonin society. Oakland: University of California Press. 
Alessa, Aziza. 2008. When Najd meets Hijaz: dialect contact in Jeddah. In: Stephan Procházka and Veronika RittBenmimoun (eds.). Between the Atlantic and Indian oceans: studies on contemporary Arabic dialects: Proceedings of the 7th AIDA Conference, Held in Vienna from 5-9 September 2006. Vienna: Lit Verlag. 51-66.

Alessa, Aziza. 2008. Najdi speakers in Hijaz: a sociolinguistic investigation of dialect contact in Jeddah. PhD thesis, University of Essex. Alghamdi, Najla Manie. 2014. A sociolinguistic study of dialect contact in Arabia: Ghamdi immigrants in Mecca. PhD thesis, University of Essex.

Al-Qahtani, Khairiah. 2015. A sociolinguistic study of the Tihami Qahtani dialect in Asir, Southern Arabia. PhD thesis, University of Essex. Al-Shihry, Mona. 2015. The emergence of a new linguistic style in Saudi Arabia. Paper presented at the 11th meeting of the Association Internationale de Dialectologie Arabe (AIDA) at the University of Bucharest.

Al-Wer, Enam. 1991. Phonological variation in the speech of women from three urban areas in Jordan. PhD thesis, University of Essex.

- 2004. Variability reproduced: a variationist view of the $[\underline{\mathrm{d}}] /[\mathrm{d}]$ opposition in modern Arabic dialects. In: Martine Haak,

Rudolph de Jong and Kees Versteegh (eds.). Approaches to A rabic dialects: collection of articles presented to Manfred Woidich on the occasion of his sixtieth birthday. Leiden: Brill.

- 2007. The formation of the dialect of Amman. In: Catherine Miller, Enam Al-Wer, Dominique Caubet, and Janet Watson (eds.). Arabic in the city: issues in dialect contact and language variation. 55-76. New York: Routledge.

Al-Wer, Enam and Khairia Al-Qahtani. 2016 (in press). Lateral fricative ḍ̄d in Tihāmat Qaḥtān: a quantitative sociolinguistic investigation. In: Stuart Davis and Usama Soltan (eds.). Perspectives on Arabic Linguistics. Amsterdam: John Benjamins.

Al-Wer, Enam and Bruno Herin. 2011. The lifecycle of qaf in Jordan. Langage et Société 138: 59-76.

Al-Wer, Enam, Uri Horesh, Bruno Herin and Maria Fanis. 2015. How Arabic regional features become sectarian features: Jordan as a case study. Zeitschrift für arabische Linguistik 62: 68-87.

Bergsträßer, Gotthelf. 1915. Sprachatlas von Syrien und Palästina. Leipzig: Hinrichs.

Bettega, Simone. 2015. Standardization, koineization and self-representation: the case of the sedentary dialects of northern Oman. Paper presented at the 11th meeting of the Association Internationale de Dialectologie Arabe (AIDA) at the University of Bucharest.

Blanc, Haim. 1953. Studies in North Palestinian Arabic: linguistic inquiries among the Druzes of Western Galilee and Mt. Carmel. Jerusalem: Israel Oriental Society.

- 1964. Communal dialects in Baghdad. Cambridge, Mass.: Harvard University Press.

Britain, David (ed.). 2007. Language in the British Isles. Cambridge: Cambridge University Press.

Caton, Steve. 1990. Peaks of Yemen, I summon: poetry as cultural practice in a north Yemeni tribe. Oakland: University of California Press.

Chambers, J. K. 1992. Dialect Acquisition. Language 68(4): 673-705.

Cotter, William M. 2016 (in press). (q) as a sociolinguistic variable in the Arabic of Gaza City. In Youssef Haddad and Eric Potsdam (eds.) Perspectives on Arabic linguistics XXVIII. Amsterdam: John Benjamins. 229-246.

Cotter, William M. and Uri Horesh. 2015. Social integration and dialect divergence in coastal Palestine. Journal of Sociolinguistics 19(4): 460-483. DOI: 10.1111/josl.12135

Deubel, Tara. 2010. Between homeland and exile: poetry, memory, and identity in Sahrawi communities. PhD dissertation, The University of Arizona.

Eckert, Penelope. 1980. Separate and unequal. Linguistics 18: 1053-1064.

- 2000. Linguistic variation as social practice. Oxford: Blackwell.

Ferguson, Charles A. 1959. Diglossia. Word 15: 325-340.

Ferguson, Charles A. and John J. Gumperz. 1960. Linguistic diversity in South Asia. International Journal of American Linguistics 26 (3), Part II.

Germanos, Marie-Aimée. and Miller, Catherine. 2014. Is religious affiliation a key factor of language variation in Arabicspeaking countries? Language \& Communication 42: 86-98.

Hachimi, Atiqa. 2013. The Maghreb-Mashreq language ideology and the politics of identity in a globalized Arab world. Journal of Sociolinguistics 17(3): 269-96.

- 2015. Policing loyalty to Moroccan Arabic on Facebook. Paper presented at the 11th meeting of the Association Internationale de Dialectologie Arabe (AIDA) at the University of Bucharest.

Haeri, Niloofar. 1996. The sociolinguistic market of Cairo: gender, class, and education. London: Kegan Paul International

—. 2000. Form and ideology: Arabic sociolinguistics and beyond. Annual Review of Anthropology 29: 61-87.

- 2003. Sacred language, ordinary people: dilemmas of culture and politics in Egypt. New York: Palgrave Macmillan.

Hassan, Zeki Majeed and Heselwood, Barry. 2011. Instrumental studies in Arabic phonetics. Amsterdam: John Benjamins.

Herin, Bruno. 2010. Le parler arabe de Salt (Jordanie). Phonologie, morphologie et éléments de syntaxe. PhD thesis, Université Libre du Bruxelles.

Herin, Bruno and Enam Al-Wer. 2013. From phonological variation to grammatical change: depalatalisation of / $\check{c} /$ in Salti. In: Clive Holes and Rudolf de Jong (eds.) Ingham of Arabia: a collection of articles presented as a tribute to the career of Bruce Ingham. Leiden: Brill. 55-73. DOI: 10.1163/9789004256194_004

Hoffman, Katherine. 2008. We share walls: language, land, and gender in Berber Morocco. Oxford: Wiley-Blackwell. 
Holes, Clive. 1987. Language variation and change in a modernising Arab state: the case of Bahrain. London: Kegan Paul International. - 2013. Orality, culture, and language. In: Jonathan Owens (ed). Oxford handbook of Arabic linguistics. Oxford: Oxford University Press. 281-299.

- 2015. Review article of Suleiman (2011). Language \& Communication 42: 99-103.

Holes, Clive and Said Salman Abu Athera. 2009. Poetry and politics in contemporary Bedouin society. Reading: Ithaca Press.

- 2011. The Nabati poetry of the United Arab Emirates. Reading: Ithaca Press.

Horesh, Uri. 2015. Structural change in urban Palestinian Arabic induced by contact with modern Hebrew. In: Aaron Michael Butts (ed.). Semitic languages in contact. Leiden: Brill. 198-233. DOI: 10.1163/9789004300156_012

Horesh, Uri and William Cotter. 2015. Sociolinguistics of Palestinian Arabic. In: Rudolf de Jong and Lutz Edzard (eds.). Encyclopedia of Arabic language and linguistics online. Leiden: Brill.

Ingham, Bruce. 1994. Najdi Arabic: Central Arabia. Amsterdam: John Benjamins.

Johnson, Daniel Ezra. 2009. Getting off the GoldVarb standard: introducing Rbrul for mixed-effects variable rule analysis. Language and Linguistics Compass 3: 359-383.

Khattab, Ghada, Al-Tamimi, Feda, and Heselwood, Barry. 2006. Acoustic and auditory differences in the /t/-/t / opposition in male and female speakers of Jordanian Arabic. In: Boudelaa, Sami (ed.). Perspectives on Arabic linguistics XVI. Amsterdam: John Benjamins. 131-160.

Khattab, Ghada. 2007. Variation in vowel production by English-Arabic bilinguals. Laboratory Phonology 9: 383-410.

- 2009. Phonetic accommodation in children's code-switching. In Barbara E. Bullock and Almeida Jacqueline Toribio (eds.). The Cambridge handbook of linguistic code-switching. New York: Cambridge University Press.

Khattab, Ghada. 2013. Phonetic convergence and divergence strategies in English-Arabic bilingual children. Linguistics 51(2): 439-472.

Labov, William. 1966. The social stratification of English in New York City, Washington, D.C.: Center for Applied Linguistics. - 1972. Sociolinguistic patterns. Philadelphia: University of Pennsylvania Press.

—. 1982. Building on empirical foundations. In: Winfred P. Lehmann \& Yakov Malkiel (eds.). Perspectives on historical linguistics. Amsterdam: John Benjamins. 17-92.

-1994. Principles of linguistic change: internal factors (Vol. 1). Malden, Mass.: Blackwell.

- 2003. Thinking about Charles Ferguson. International Journal of the Sociology of Language 163: 5-7.

Leddy-Cecere, Thomas. 2015. A linguistic reevaluation of the Egypto-Sudanese dialect grouping. Paper presented at the 11th meeting of the Association Internationale de Dialectologie Arabe (AIDA) at the University of Bucharest.

Meyerhoff, Miriam. and Walker, James A. 2013. An existential problem: the sociolinguistic monitor and variation in existential constructions on Bequia (St. Vincent and the Grenadines). Language in Society 42(4): 407-428.

Miller, Flagg. 2007. The moral resonance of Arab media: audiocassette poetry and culture and Yemen. Cambridge: Harvard University Press Miller, Flagg. 2008. Al-Qa'ida as a 'pragmatic base': contributions of area studies to sociolinguistics. Language E Communication 28(4): 386-408.

Milroy, Lesley. 1987. Language and social networks. Oxford: Blackwell.

Owens, Jonathan. 2001. Arabic sociolinguistics. Arabica 48: 419-469.

—. 2011. Arabic sociolinguistics. In: Stefan Weninger, Geoffrey Khan, Michael P. Streck, and Janet C.E. Watson (eds.). The Semitic languages: an international handbook. 970-981. Berlin: De Gruyter.

Owens, Jonathan. 2014. The morphologization of an Arabic creole. Journal of Pidgin and Creole Languages 29(1): 232-298. DOI: 10.1075/jpcl.29.1.03owe

Sayahi, Lotfi. 2014. Diglossia and language contact: language variation and change in North Africa. Cambridge: Cambridge University Press.

Schroepfer, Jason. 2015. A cognitive approach to describing Aswan Arabic demonstratives. Paper presented at the 11th meeting of the Association Internationale de Dialectologie Arabe (AIDA) at the University of Bucharest.

Schulthies, Becky. 2015. Do you speak Arabic? Managing axes of adequation and difference in pan-Arab talent programs. Language \& Communication 44: 59-71.

Sidnell, Jack. 2001. Conversational turn-taking in a Caribbean English creole. Journal of Pragmatics 33: 1263-1290.

- 2012. Language and gender in the Caribbean. Journal of Pidgin and Creole Languages 27(1): 141-157.

Singler, John Victor. 1990. On the use of sociohistorical criteria in the comparison of creoles. Linguistics 28(4): 645-659.

Suleiman, Yasir. 2011. Arabic, self and identity: a study in conflict and displacement. Oxford: Oxford University Press.

Tagliamonte, Sali. 2006. Analysing sociolinguistic variation. Cambridge: Cambridge University Press.

Theodoropoulou, Irene. 2015. Sociolinguistic anatomy of mobility: evidence from Qatar. Language E Communication 40 : 52-66.

Tosco, Mauro. and Manfredi, Stefano. 2013. Pidgins and creoles. In Jonathan Owens (ed.). The Oxford handbook of Arabic linguistics. Oxford: Oxford University Press. 495-519.

Trudgill, Peter. 1974. The social differentiation of English in Norwich. Cambridge: Cambridge University Press.

- (ed.). 1984. Language in the British Isles. Cambridge: Cambridge University Press.

- 1986. Dialects in contact. Oxford: Blackwell. 
Versteegh, Kees. 1984. Pidginization and creolization: the case of Arabic. Amsterdam: John Benjamins.

- 2004. Pidginization and creolization revisited: the case of Arabic. In: Martine Haak, Rudolph de Jong and Kees Versteegh (eds.). Approaches to Arabic dialects: collection of articles presented to Manfred Woidich on the occasion of his sixtieth birthday. Leiden: Brill. 359-372.

Walters, Keith. 1996. Diglossia, linguistic variation, and language change in Arabic. In: Mushira Eid (ed.). Perspectives on Arabic linguistics: papers from the annual symposium on Arabic linguistics. Volume VIII: Amherst, Massachusetts 1994. Amsterdam: John Benjamins. 157-197.

Wolfram, Walt and Natalie Schilling. 2016. American English: dialects and variation, 3rd Edition. Malden, Mass.: WileyBlackwell. 